\title{
Ex vivo model for studying polymicrobial biofilm formation in root canals
}

\author{
Francisco Correa Toral ${ }^{1}$, Leylin Delgado Hernández ${ }^{1}$, Carolina Echavarría González ${ }^{1}$, \\ Fátima Serna Varona ${ }^{1}$, Adriana Rodríguez Ciodaro ${ }^{1}$, Hugo Díez Ortega ${ }^{2, *}$
}

\author{
Edited by \\ Juan Carlos Salcedo-Reyes \\ (salcedo.juan@javeriana.edu.co) \\ 1. Center for Dental Research, \\ School of Dentistry, Pontificia \\ Universidad Javeriana. Bogotá, \\ Colombia. \\ 2. Infectious Diseases Group, \\ School of Sciences, \\ Department of Microbiology, \\ Pontificia Universidad Javeriana. \\ Bogotá, Colombia. \\ *hugo.diez@javeriana.edu.co
}

Received: 09-03-2016

Accepted: 16-11-2016

Published on line: 16-12-2016

Citation: Correa Toral F, Delgado Hernández L, Echavarría González C, Serna Varona F, Rodríguez Ciodaro A, Díez Ortega H. Ex vivo model for studying polymicrobial biofilm formation in root Canals, Universitas Scientiarum, 22 (1): 31-43, 2017. doi: 10.11144/Javeriana.SC22-1.evmf

Funding: This project was funded by the Center for Dental Research and its research line on Oral Pathologies and the Group of Infectious diseases and its research line Molecular and Applied Microbiology at Pontificia Universidad Javeriana.

Electronic supplementary material: N.A. ACCESS

\begin{abstract}
Endodontic disease has mainly a microbial origin. It is caused by biofilms capable of attaching and surviving in the root canal. Therefore, it is important to study the conditions in which those biofilms grow, develop and colonize the root canal system. However, few studies have used natural teeth as models, which would take into account the root canal anatomical complexity and simulate the clinical reality. In this study, we used human premolar root canals to standardize in vitro biofilm optimal formation conditions for microorganisms such as Enterococcus faecalis, Staphylococcus aureus and Candida albicans. 128 lower premolars underwent canal preparation using K-type files, and were treated with 5.25\% sodium hypochlorite and EDTA. Samples were inoculated with microorganisms and incubated for $15,30,45$, and 60 days under anaerobiosis $\left(\mathrm{CO}_{2}\right.$ atmosphere) and aerobiosis. Microorganism presence was confirmed by Gram staining, cell culture, and electron microscopy. Exopolysaccharide matrix and microorganism aggregation were observed following 15 days of incubation. Bacterial growth towards the apical third of the root canal and biofilm maturation was detected after 30 days. $\mathrm{CO}_{2}$ atmosphere favored microbial growth the most. In vitro biofilm maturation was confirmed after 30 days of incubation under a $\mathrm{CO}_{2}$ atmosphere for both bacteria and yeast.
\end{abstract}

Keywords: Dental Pulp Diseases, Biofilm, microbial interactions, Enterococcus faecalis, Staphylococcus aureus, Candida albicans.

\section{Introduction}

Biofilm is the most common system of microbial organization. It is formed by one or several microorganisms attached to a living or inert surface. Biofilms possess functional characteristics and complex structures. In a biofilm, microorganisms are wrapped in an extra-cellular matrix made of polysaccharides that display a tulip or mushroom shape with the presence of internal water channels. Additionally, biofilms form interaction stages between microorganisms and host cells creating a metabolic community that contributes in a complex manner to the microorganism's survival. 
Biofilm formation confers bacteria phenotypic characteristics that are not seen in the planktonic state. Under this state microorganisms can change their individual, genetic and physiological characteristics. This allows microorganisms not only to achieve a higher survival rate, but also to acquire virulence characteristics of other microorganisms present in the biofilm. This is clinically significant since the host's defense system and other mechanisms including chemical or mechanical treatments are not sufficient to eradicate infections that become persistent [1-5].

Dental pulp is a structure composed of soft connective tissue, blood vessels, and nerves located in root canals. They are surrounded by enamel and dentin that act as a barrier to avoid microorganism contamination. However, when teeth hard tissues are destroyed by dental or periodontal infections and trauma, microorganisms can penetrate through the pulp. This causes inflammation followed by pulp and periapical tissue necrosis. Therefore, to preserve the tooth, it is necessary to perform endodontic treatment, removing microorganisms from the root canal. To this end, chemo-mechanical debridement of dentin walls must be performed with sealing to prevent re-contamination. Nevertheless, sometimes a correctly performed endodontic treatment can fail due to apical radicular dentinal tubule microorganism invasion capable of adhering and surviving in the root canal by biofilm formation $[1,3,6-8]$.

Endodontic pathogenic microorganisms are defined by their capacity to induce tissue destruction in apical periodontitis. Thus, they must have efficient adaptive mechanisms allowing them to survive such environment including $\mathrm{pH}$ regulation, tolerance to temperature changes, equilibrated substrate utilization, facultative oxygen management, adhesion protein expression, biofilm formation, and the ability to interact with other microorganisms. These factors endow bacteria with diverse phenotypic features that enable them to survive in hostile environments and make them more virulent $[1,3,9-10]$.

Although many microorganisms that cause persistent endodontic infections have been identified, most studies have focused on evaluating new antimicrobial irrigant effectiveness and different preparation techniques used to eliminate biofilm formed only by one microorganism, mainly Enterococcus faecalis (EF). However, considering polymicrobial endodontic re-infection, recent studies have employed multispecies biofilm formed by two or more microorganisms including Enterococcus, Streptococcus sp., Candida albicans and Staphylococcus sp. [11-14]

Enterococcus faecalis is described as the primary cause of persistent endodontic infections. It has often been detected in root canal system infections, when endodontic treatment fails. Enterococcus faecalis has a high capacity to survive and grow in microenvironments with the presence of calcium hydroxide resulting in colonization and root canal infection. [15-17]. Another species related to dental intracanal biofilm formation is Sthaphylococcus aureus (SA). This is a facultative anaerobic, immobile, nonsporulated, Gram-positive coccus, which is source of periodontal, periapical, and endodontic infections $[18,19]$.

Even though fungi are not frequently detected in primary endodontic infections, its presence is related to endodontically filled teeth with peri-radicular lesions resistant to root canal treatment. In addition, they can be the result of disease management 
contamination. It has been reported that yeasts like Candida albicans (CA) have the ability to grow as mono-infections and invade dentinal tubules through pseudo-mycelia. Moreover, is also commonly found in some cases of persistent endodontic disease [18-20].

A variety of models have been used for biofilm formation, but few studies have used natural teeth, simulating the clinical reality taking into account root canal anatomical complexity. Therefore, the objective of this study was to standardize optimal in vitro conditions for endodontic biofilm formation. These included: atmosphere, incubation period, and detection. Three microorganisms were evaluated on human premolar root canals: Enterococcus faecalis, Staphylococcus aureus, and Candida albicans. This represents a starting point for new projects to characterize bacterial root canal behavior, and identify the most appropriate method for elimination.

\section{Materials and Methods}

This study was carried out in accordance with the recommendations of the Research and Ethics Committee of Dental School at Pontificia Universidad Javeriana. All subjects gave written informed consent in accordance with the Declaration of Helsinki. The present study used 128 lower premolars that were extracted for orthodontic purposes and had no periodontal disease, previous endodontic treatment or restorations

Dental crowns were removed and root length was standardized to $16 \mathrm{~mm}$, followed by $5.25 \%(\mathrm{v} / \mathrm{v})$ sodium hypochlorite $(\mathrm{NaOCl})$ immersion for 30 minutes, to remove remaining organic tissue. Corono-apical technique $1 \mathrm{~mm}$ below the apical foramen was used for root canal preparation employing a K-type file \# 50. In addition, $3 \mathrm{ml}$ of $5.25 \% \mathrm{NaOCl}$ was used for irrigation between each file. Subsequently, root canals were dried and soaked in $17 \%$ EDTA for 3 minutes for dentin detritus removal. Each premolar was then sterilized in autoclave at $120^{\circ} \mathrm{C}$.

The experimental system was designed by placing a root into a sterile $1.5 \mathrm{ml}$ polypropylene tube (Eppendorf, Hauppauge, NY USA) cut off at the distal end, sealed with cyanoacrylate adhesive and epoxy resin. Moreover, it was covered with two coats of nail polish. Each tube-root system was sterilized in $5 \% \mathrm{NaOCl}$ for 30 minutes and then washed with sterilized water for 30 minutes.

Enterococcus faecalis 9212, Staphylococcus aureus 29213, and Candida albicans 10231 ATCC strains were used. Selective media Enterocult agar was used for Enterococcus faecalis microbiological confirmation. Colonies with morphological and stain characteristics compatible with the genus were identified using biochemical tests such as catalase, PYR, $6.5 \% \mathrm{NaCl}$, hemolysis on blood agar, Inulin, Mannitol, and Bile esculin agar followed by semiautomatic Micro Scan system confirmation (Dade Behring Microscan, West Sacramnento CA, EEUU).

Staphylococcus aureus was confirmed by Trypticase Soy Agar primary isolation. Colonies with morpho-tinctorial characteristics (Gram Staining) of the Staphylococcus genus were selected from this media. Subsequently, biochemical identification tests such as catalase, DNAase agar, Mannitol were carried out, followed by Micro Scan system confirmation [21]. 
Candida albicans confirmation was first carried-out by primary Sabourad agar isolation. Gram staining was used to analyze typical conidia and blastoconidia. In addition, it was grown on CHROMagar Candida Medium (CHROMagar, Microbiology, France). Moreover, biochemical identification tests such as urease, auxonogram for carbohydrate assimilation and filamentation at $42{ }^{\circ} \mathrm{C}$ were performed. Candida spp. manually identified colonies were confirmed using Micro Scan automated panel.

Each microorganism was proliferated in brain heart infusion broth $(\mathrm{BHI})$ at $37{ }^{\circ} \mathrm{C}$ for $24 \mathrm{~h}$. Samples were centrifuged and re-suspended in an isotonic saline buffer supplemented with BHI broth until reaching an approximate final concentration of $3 \times 10^{8}$ cells $/ \mathrm{mL}$, corresponding to an absorbance of 0.200 from turbidity tube No. 1 of McFarland's nephelometer.

128 experimental systems were incubated in a moist chamber at $37{ }^{\circ} \mathrm{C}$ under two different atmospheres: 64 in aerophilic atmosphere and 64 in microaerophilic $\left(10 \% \mathrm{CO}_{2}\right)$. From these, eight groups with eight experimental systems were inoculated in the following manner: 1 Enterococcus faecalis (EF), 2 Staphylococcus aureus (SA), 3 Candida albicans (CA), 4 Negative control (NC), 5 (EF + SA), $6(\mathrm{EF}+\mathrm{CA}), 7(\mathrm{SA}+\mathrm{CA}), 8(\mathrm{EF}+\mathrm{SA}+\mathrm{CA}) .50 \mu \mathrm{l}$ from each ATCC strain were inoculated in each experimental system. All experiments were carried-out in duplicates, and evaluations were performed after 15, 30, 45 and 60 days.

Microbial growth was confirmed introducing sterile absorbent paper strips for 2 - 3 minutes into root canals of all experimental systems. Each paper strip was submerged in $7 \mathrm{~mL}$ BHI broth and it was incubated at $37^{\circ} \mathrm{C}$ for $24 \mathrm{~h}$. Microbial growth was evaluated using three basic parameters: culture media turbidity, Gram staining, and biochemical identification. Negative controls were evaluated under the same experimental conditions.

Biofilm formation was confirmed by electron microscopy. To this end, experimental systems were sectioned by cryo-fracture with liquid nitrogen and subsequently subjected to gold metallography preparation for Scanning Electron Microscope (SEM) analysis (JEOL, Peaboy MA USA Model JSM 6490-LV).

For biofilm formation evaluation, the apical portion of the crown root cut was observed and two micrographs for each sample were recorded: one performed on the coronal third and the other on the apical third at $5.000 \mathrm{X}(1 \mu \mathrm{m})$ and 20.000 $\mathrm{X}(5 \mu \mathrm{m})$ magnification, respectively. All samples were analyzed including controls.

\section{Results}

Optimal Period of Time for Biofilm Formation: After having conducted microbiological evaluation and biofilm detection by SEM on each tooth, it was evidenced biofilm formation was observed primarily on surface areas after 15 days: in aerophilic media and microaerophilic media. In contrast, on apical zones adherence and invasion phenomena were detected, but no biofilm formation was recorded.

Microbial functional interactions within extracellular polymeric matrix on the apical third of the root canal were noted. A complete surface-associated growth was obtained 

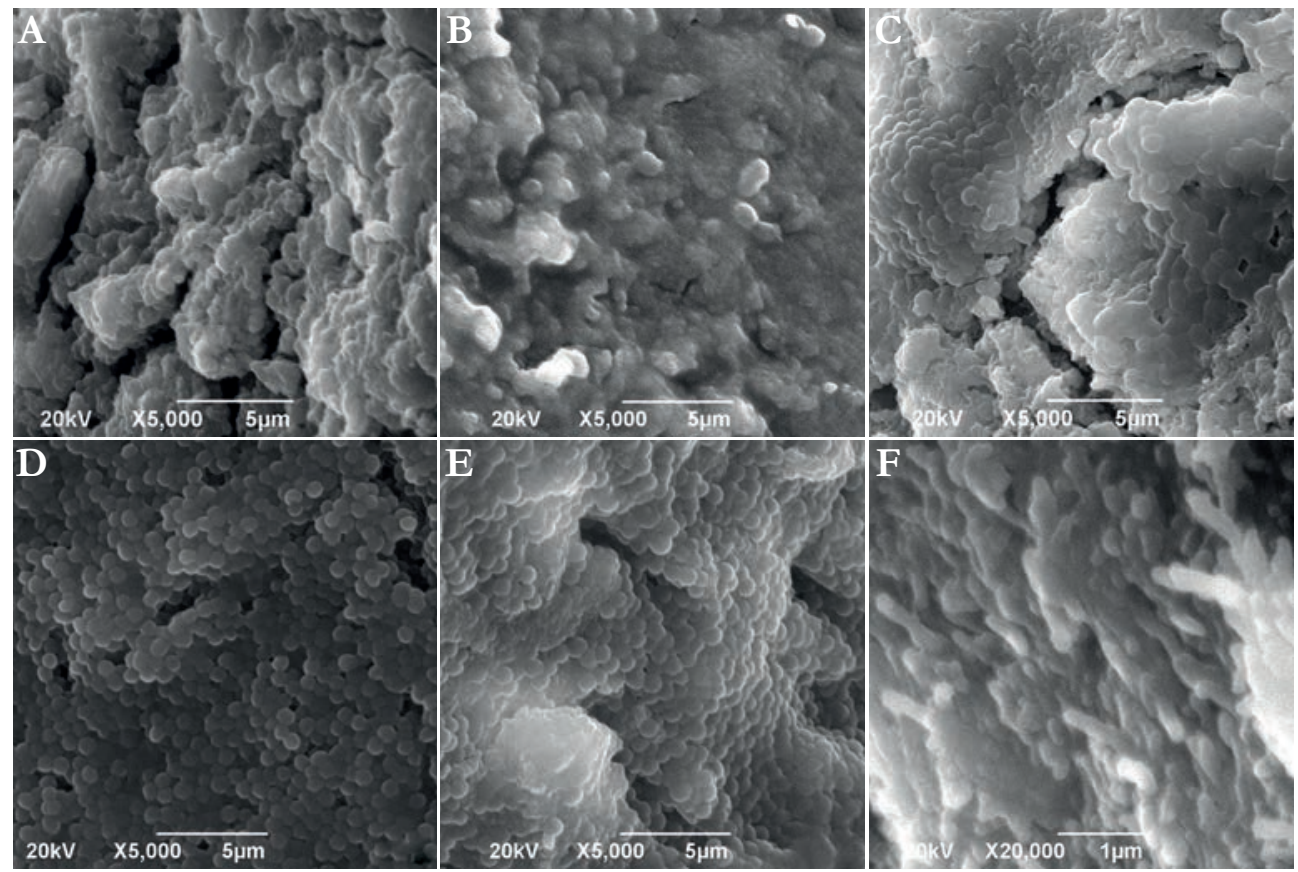

Fig. 1. Comparison between cultures in aerophilic media (top micrographs) and microaerophilic media (bottom micrographs) in the apical tooth portion after 30 days of incubation. (A) Micrograph of E. faecalis $+S$. aureus $+\mathrm{O}_{2}$ culture. (B) Micrograph of E. faecalis + C. albicans $+\mathrm{O}_{2}$ culture. (C) Micrograph of E. faecalis $+C$. albicans $+S$. aureus $+\mathrm{O}_{2}$ culture. (D) Micrograph of E. faecalis $+S$. aureus $+\mathrm{CO}_{2}$ culture. (E) Micrograph of E. faecalis + C. albicans $+\mathrm{CO}_{2}$ culture. (F) Micrograph of E. faecalis + C. albicans + S. aureus $+\mathrm{CO}_{2}$ culture. $5,000 \mathrm{X}$. Scale bar $5 \mu \mathrm{m}$.

after 30 days of incubation (Figure 1). Subsequent evaluations made it possible to observe that these conditions remained up to 45 days. Therefore, no further SEM analyses were performed after 45 and 60 days.

Once the effect of oxygen as a factor on biofilm development was analyzed, it was evidenced under anaerobic atmosphere biofilm developed on the surface area after 15 days. Although bacterial aggregates on dentin surface at the coronal third of the root was observed, dentinal tubules were still visible. However, at the apical level no bacterial growth was detected for any of the analyzed samples (Figure 2). Never the less, bacteria presented a better development in terms of growth as biofilm at $10 \%$ $\mathrm{CO}_{2}$. Under these conditions, a better bacterial aggregation on the dentin surface without presence of dentinal tubules on the coronal portion was observed (Figure 3). Under $\mathrm{CO}_{2}$ atmosphere, the only microbial combination capable of growing on the apical third during this period of time was CA and EF. This was evident taking into account the aforementioned recovered CFU.

On the dentinal surface a better formed biofilm and well developed structures were observed along the entire canal. However, regarding aerophilic cultures, it was possible to evidence the presence of some dentinal tubules on apical portions. In contrast, microaerophilic cultures seemed to grow even better on the apical fraction.

Biofilm Maturity: Scanning electron microscopy results evidenced microorganisms surrounded by glycocalyx and adhered to a hard surface. The matrix formed by the 

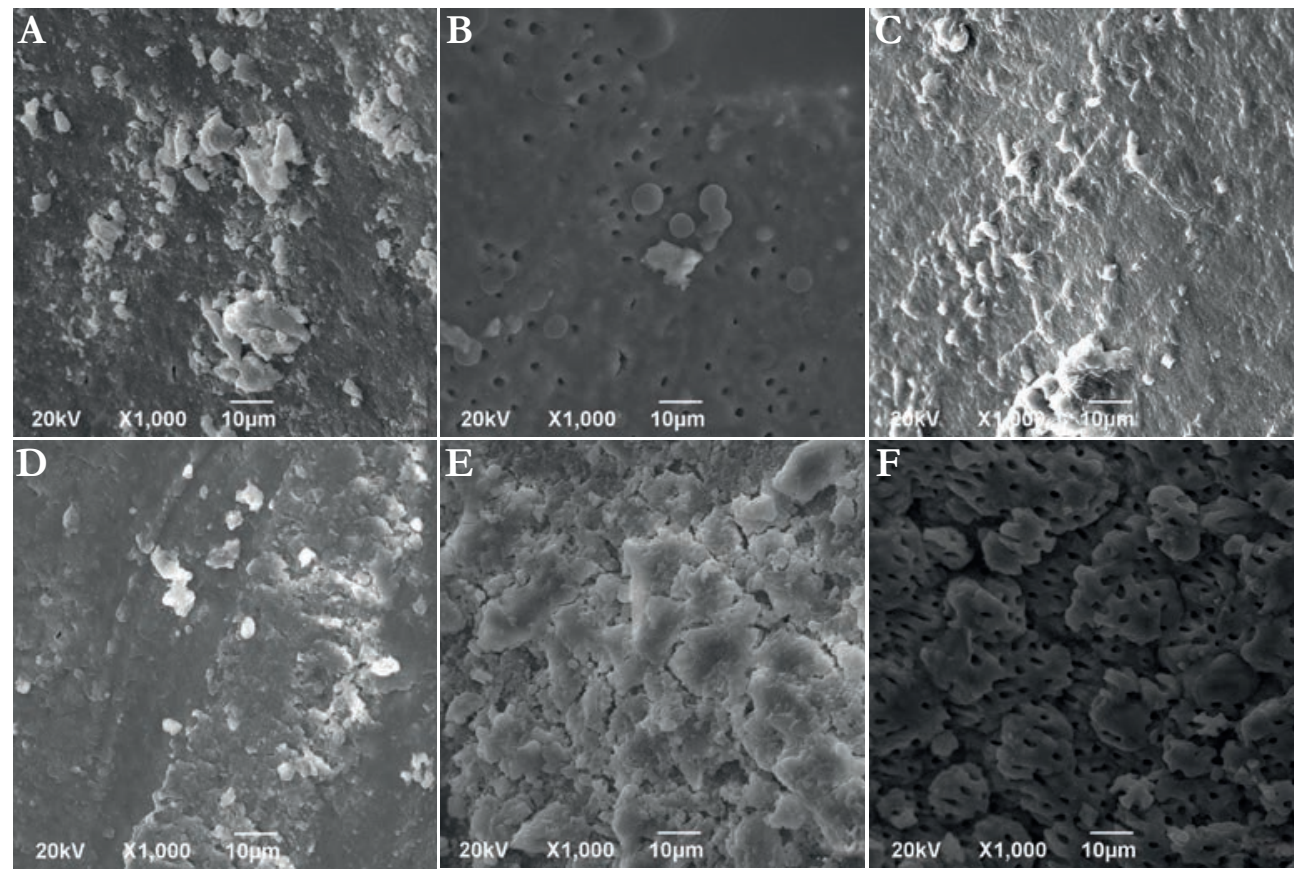

Fig. 2. SEM Micrographs on the apical parts and teeth crown performed after 15 days of culture. (A) Micrograph of E. faecalis culture. (B) Micrograph of C. albicans culture. (C) Micrograph of E. faecalis + C. albicans culture. (D) Micrograph of C. albicans + S. aureus culture. (E) Micrograph of E. faecalis $+C$. albicans $+S$. aureus culture. $(\mathbf{F})$ Micrograph of apical portion where no growth was observed. 1,000 X. Scale bar $10 \mu \mathrm{m}$.

combination of EF, SA, and CA under an aerophilic atmosphere and incubated for 15 days demonstrated greater bacterial growth and biofilm behavior, than that observed in the anaerobic environment.

Identification and Detection of Microbial Morphotypes: Gram staining microscopic observations and solid culture media colony macroscopic characteristics made it possible to select colonies for each of the microorganisms used in the experimental phase. Such colonies were identified through manual and Micro Scan systems getting a concordance rate of $100 \%$ with respect to the inoculated microorganism in each root canaliculi. Isolation and identification were useful to simultaneously evaluate culture purity after inoculating a tooth. Results revealed 100 $\%$ pure isolation. Furthermore, as established by Gram staining negative controls did not have microorganisms, thus cultures were $100 \%$ negative for bacterial growth.

\section{Discussion}

This study evaluated three factors possibly affecting root canal biofilm growth and development, namely: $\mathrm{O}_{2}$ concentration, microbiota etiology in a timely associated processes, and species interaction. For this latter one E. faecalis (EF), S. aureus (SA), and $C$. albicans (CA) were evaluated for adherence and virulence features.

After 15 days of incubation at $37^{\circ} \mathrm{C}$, it was observed for both atmospheres $\left(\mathrm{O}_{2}\right.$ and $10 \% \mathrm{CO}_{2}$ ) that microorganisms formed an exopolysaccharide matrix, with initiation 

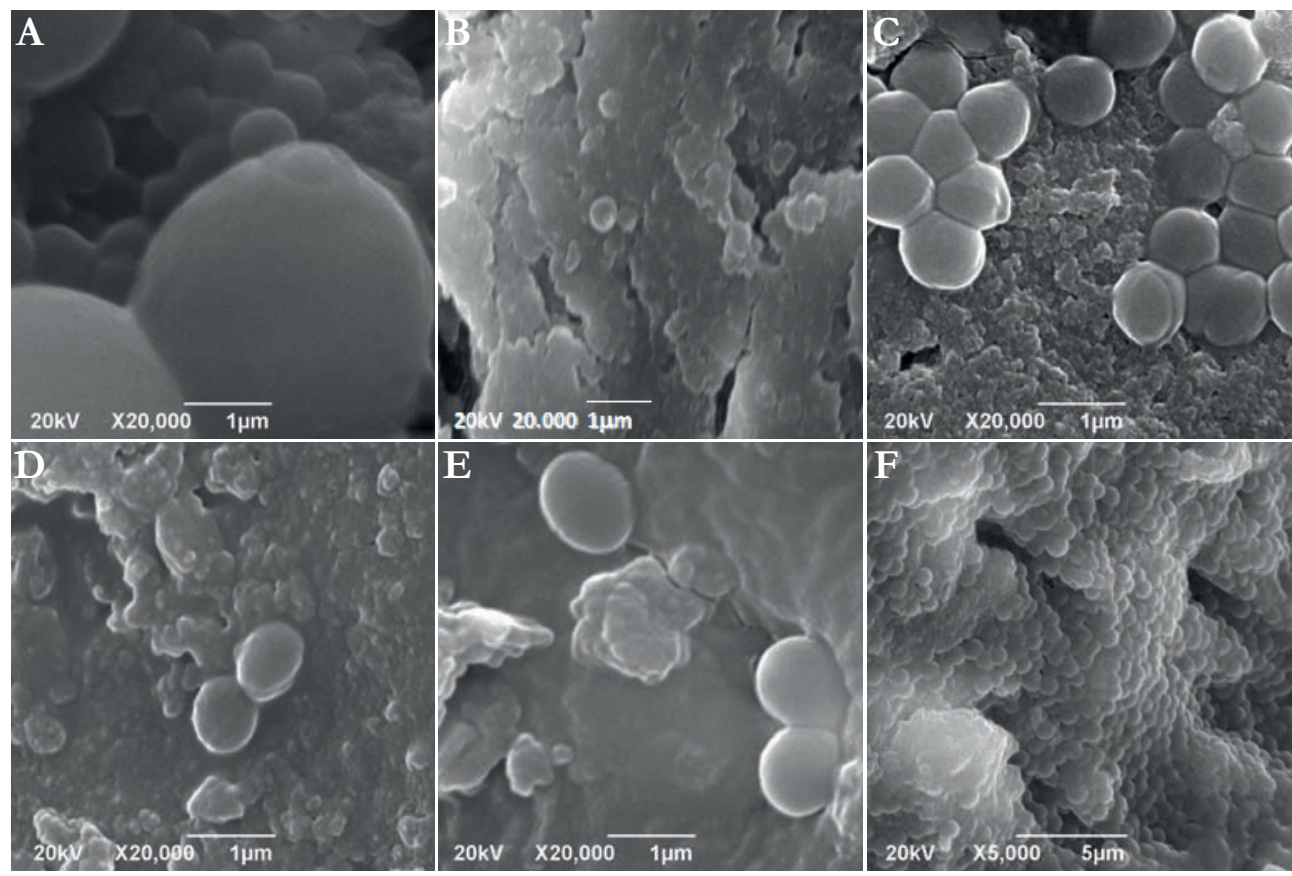

Fig. 3. SEM micrographs of crown and apical portion of teeth performed after 15 days of culture under microaerophilic media. (A) Micrograph of C. albicans culture. (B) Micrograph of E. faecalis + S. aureus culture. (C) Micrograph of E. faecalis + C. albicans culture. (D) Micrograph of C. albicans + S. aureus culture. (E) Micrograph of E. faecalis $+C$. albicans $+S$. aureus culture. (F) Micrograph of E. faecalis + C. albicans culture on the apical portion. 20,000 X. Scale bar $1 \mu \mathrm{m}$.

of surface-adhesion and cell division. Proliferation grew exponentially after 30 days in reduced oxygen atmosphere. SEM revealed a consolidated and mature biofilm with deep penetration of the microorganism into the dentinal tubules. As a case in point it has been proposed for $\mathrm{EF}$ that biofilm formation is a response mechanism against adverse environmental conditions; displaying important clonal variation in their ability to form this biofilm [22].

Similary to our study other authors detected that EF formed bacterial aggregations together with an exopolysaccharide layer adhered to root canal walls at week two. Furthermore, at week four it was able to develop co-aggregates covering the dentin surface $[23,24]$.

Conditions of aerobiosis, microaerophilic, and anaerobic atmospheres on paper or nylon matrixes and direct cultures among others have been evaluated. The authors recognize that reduced molecular oxygen at the root canal level benefits biofilm formation, and can increase antimicrobial agent resistance. Therefore, it is important to standardize optimal $\mathrm{O}_{2}$ conditions for an in vitro biofilm model: this represents a great advancement to evaluate antimicrobial sensitivity and environmental resistance to microorganisms, especially EF [25, 26].

The current study established that microorganisms remained viable during the whole experiment. Additionally, pure strains were isolated free of any contamination. Individual count for every microorganism evaluated made it possible to establish a 
growth pattern resembling the classical microbial growth curve. Initially, a lag phase did not exceed $1 \times 10^{2} \mathrm{CFU} / \mathrm{mL}$. Subsequently, log phase counts ranged between 1 $\mathrm{x} 10^{4} \mathrm{CFU} / \mathrm{mL}$ to $1 \times 10^{7} \mathrm{CFU} / \mathrm{mL}$. Last, while in the stationary phase and decline phase microbial population decreased to $1 \times 10^{2} \mathrm{CFU} / \mathrm{mL}-1 \times 10^{4} \mathrm{CFU} / \mathrm{mL}$. In systems where two or three microorganisms were combined, a greater growth was observed, when compared with only one species interaction. It is likely under more than one species microorganisms can exchange substrates and nutrients. When comparing SA to EF or CA, it was observed that the initial growth was slow and required interaction with other microorganisms to improve development and maturity. CA and EF have the ability to grow as mono-infections because they are microorganisms with multiple pathogenicity factors, such as adhesion proteases, resistance to high temperature ranges, tolerance to wide $\mathrm{pH}$ ranges; additionally, they were able to survive nutrient shortage. These features demonstrate that they are aggressive microorganisms, not depending on bacterial interactions for their development and growth [27, 28].

A mature biofilm and rapid growth was observed by SEM analysis for both aerophilic and microaerophilic cultures when three microorganisms interacted in a same root canal. This suggests bacteria colonized a space and performed a specific function. Microorganisms in a sessile state possess mechanisms to protect themselves against the environment (immune system, antibiotics, or disinfectants). Furthermore, it is an efficient system to capture nutrients, and cross feeding strategy between species can take place. In addition, toxic metabolites can be removed, last develop an appropriate environment with physicochemical conditions for growth [4].

Although an in vivo biofilm formation occurs spontaneously and requires a low rate of nutrients, the development of each of its stages and required generation time differs considerably from an in vitro scenario. Experimental models do not involve the totality of microorganisms. There is no evidence of active supply of external nutrients or intervention of host factors during the process. Furthermore, some stages of biofilm development such as dispersion, absorption and fixation depend on quality and type of adhesive material used in the experimental model. Hence, data from biofilm formation in vitro cannot be explored at the same level of in vivo biofilm formation [4].

This standard model revealed the optimal period of time for immature biofilm establishment on surfaces occurred after 15 days. In contrast, mature biofilm formation including apical third of root canal invasion occurred after 30 days. Experimental designs intended to standardize in vitro biofilm formation methods have contradicting results with studies reporting growth ranging from three days to even 60 days [26, 29].

SEM data demonstrated biofilms grew more rapidly on the apical region due to $\mathrm{CO}_{2}$ presence. This was mainly the case for EF and the combination of three microorganisms $(\mathrm{EF}+\mathrm{SA}+\mathrm{CA})$. $\mathrm{CA}$ and $\mathrm{SA}$ independent cultures did not form any mature or compact film.

Additionally, differences in time may be related to various experimental factors such as biofilm growth on a solid-liquid medium. In addition, fluid medium irrigation velocity may influence nutrient transport, toxic molecule elimination, and detachment of microorganisms. Likewise, experimental models do not possess substrates that are 
supplied by the various interrelations between other bacteria Fusobacterium, Eubacterium, Bacteroides, Capnocytophaga, Eikenella, Streptococcus, Actinomyces, Campylobacter, Porphyromonas such as hemin, succinate, ammonia, formate, acetate, menadione among others. These substrates influence the rate of adaptation to the biological niche and also the scale of biofilm formation [30].

The time needed for biofilm formation on an infected root canal depends on the use of disinfectant and alkalizing substances such as calcium hydroxide, presence or absence of exudate from the root canal, the type of microorganisms involved, and its location on the root canal. These variables are not considered in in vitro models $[31,32]$.

Other studies have contributed to evidence EF ability to colonize mechanically and chemically treated root canals. EF has the capacity to adhere on the dentine surface to collagen, where protease synthesized by bacteria and collagen binding protein (Ace) are probably related to the process of bacterial adhesion. Thus, allowing bacteria to colonize the root canal [33].

From this experimental design it was possible to infer that there is no unique biofilm model. Therefore, individual contribution of each variable from the proposed model should be analyzed. This is necessary in order to determine the adequate environmental conditions for development and modifications of biofilms formed on the root canal, as well as their capacity of penetration into the dentinal tubules.

\section{Conclusions}

The in vitro biofilm model formed by micro-organisms such as EF, CA and SA grew best in microaerophilic atmospheres of $10 \% \mathrm{CO}_{2}$ at $37{ }^{\circ} \mathrm{C}$. Biofilm maturation and development was attained on the entire root surface after 30 days of incubation.

Bacteria inoculated as a group had a much more rapid growth in comparison with individual inoculations. This can be attributed to synergistic and additive interactions among them.

Understanding the capacity of these microorganisms, individually and collectively to form biofilm within the root canal fosters a novel approach to the physiopathology of the infectious process. Furthermore it provides a standardized in vitro model that will be useful to evaluate the antimicrobial effect of irrigants, chelating and antiseptic solutions on these biofilms.

\section{Acknowledgements}

This project was funded by the Center for Dental Research and its research line on Oral Pathologies and the Group of Infectious diseases and its research line Molecular and Applied Microbiology at Pontificia Universidad Javeriana.

\section{Conflict of interest}

The authors of this manuscript have no conflict of interests to declare. 


\section{References}

1. Sundqvist G, Figdor D. Life as an endodontic pathogen. Ecological differences between the untreated and root-filled root canals. Endodontic Topics, 6: 3 - 28, 2003.

doi: 10.1111/j.1601-1546.2003.00054.x

2. Donlan RM, Costerton JW. Biofilms: survival mechamisms of clinically relevant microorganisms. Clinical Microbiology Reviews, 15: 167 - 93, 2002.

doi: 10.1128/CMR.15.2.167-193.2002

3. Usha HL. Biofilm in endodontics: New understanding to an old problem. International Journal of Contemporary Dentistry, 1: 44 - 50, 2010.

4. Flemming H, Jost Wingender J. The biofilm matrix. Nature Reviews Microbiology, 8: 623 - 33, 2010.

doi: $10.1038 /$ nrmicro2415

5. Stewart P, Franklin M. Physiological heterogeneity in biofilms. Nature Reviews Microbiology, 6: 199 - 210, 2008.

doi: $10.1038 /$ nrmicro1838

6. Nair PN. On the cause of persistent apical periodontitis: a review. International Endodontic Journal, 39: 249 - 81, 2006.

doi: 10.1111/j.1365-2591.2006.01099.x

7. Svensäter G, Bergenholtz G. Biofilm in Endodontic infections. Endodontic Topics, 9: 27 - 36, 2004.

doi: 10.1111/j.1601-1546.2004.00112.x

8. Siqueira J, Rocas I, Ricucci D. Biofilms in endodontic infection. Endodontic Topics, 22(1): $33-49,2010$.

doi: 10.1111/j.1601-1546.2012.00279.x

9. Merino R, Guilarte C, Pardi G. Actualización taxonómica de la microbiota implicada en infecciones endodónticas. Acta Odontológica Venežlana, 43: 327 - 329, 2007.

10. Sbordone L, Bortolaia C. Oral microbial biofilms and plaque-related diseases: microbial communities and their role in the shift from oral health to disease. Clinical Oral Investigation, 7: $181-8,2003$.

doi: 10.1007/s00784-003-0236-1

11. Barros J, Dias A, Rodrigues MA, Pina-Vaz C, Lopes MA, Pina-Vaz I. Antibiofilm and antimicrobial activity of Polyethylenimine: An interesting compound for endodontic treatment. The Journal of Contemporay Dental Practice, 16: 427 - 32, 2015.

12. Abbaszadegan A, Gholami A, Mirhadi H, Saliminasab M, Kazemi A, Moein MR. Antimicrobial and cytotoxic activity of Ferula gummosa plant essential oil compared to $\mathrm{NaOCl}$ and $\mathrm{CHX}$ : a preliminary in vitro study. Restorative Dentistry \& Endodontics, 40: $50-7,2015$.

doi: 10.5395 / rde.2015.40.1.50

13. Mistry KS1, Sanghvi Z2, Parmar G3, Shah S4, Pushpalatha K. Antibacterial efficacy of Azadirachta indica, Mimusops elengi and $2 \%$ CHX on multispecies dentinal biofilm. Journal of Conservative Dentistry, 18: 461 - 66, 2015.

doi: 10.4103/0972-0707.168810 
14. Jose J, Krishnamma S, Peedikayil F, Aman S, Tomy N, Mariodan JP. Comparative evaluation of antimicrobial activity of QMiX, 2.5\% Sodium Hypochlorite, $2 \%$ Chlorhexidine, Guava Leaf extract and Aloevera extract against Enterococcus faecalis and Candida albicans - An in-vitro Study. Journal of Clinical \& Diagnostic Research,10: ZC20 - ZC23, 2016.

doi: $10.7860 / J C D R / 2016 / 17705.7747$

15. Gomes B, Pinheiro E, Gade-Neto C, Sousa E, Ferraz C, Zaia A, Teixeira F, Souza-Filho F. Microbiological examination of infected dental root canals. Oral Microbiology and Immunology, 19: $71-6,2004$.

doi: 10.1046/j.0902-0055.2003.00116.x

16. Peciuliene V, Reynaud A, Balciuniene I, Haapasalo M. Isolation of yeasts and enteric bacteria in root-filled teeth with chronic apical periodontitis. International Endodontic Journal, 34: 429 - 34, 2001.

doi: 10.1046/j.1365-2591.2001.00411.x

17. Kayaoglu G., Orstavik D. Virulence Factors of Enterococcus faecalis: relationship to endodontic disease. Critical Reviews in Oral Biology and Medicine, 15: 308 - 20, 2009.

doi: 10.1177/154411130401500506

18. Pinheiro ET, Gomes BP, Ferraz CC, Sousa EL, Teixeira FB, Souza-Filho FJ. Microorganisms from canals of rootfilled teeth with periapical lesions. International Endodontic Journal, 36: $1-11,2003$.

19. Reader CM, Boniface M, Bujanda-Wagner S. Refractory endodontic lesion associated with Staphylococci aureus. Journal of Endodontics, 20: 607 - 09, 1994.

20. Peciuliene V, Reynaud AH, Balciuniene I, Haapasalo M. Isolation of yeasts and enteric bacteria in root-filled teeth with chronic apical periodontitis. International Endodontic Journal, 34: 429 - 34, 2001.

21. Evans M, Davies JK, Sundqvist G, Figdor D. Mechanisms involved in the resistance of Enterococcus faecalis to calcium hydroxide. International Endodontic Journal, 35: 221 - 8, 2002.

doi: 10.1046/j.1365-2591.2002.00504.x

22. Wilson CE, Cathro PC, Rogers AH, Briggs N, Zilm, PS. Clonal diversity in biofilm formation by Enterococcus faecalis in response to environmental stress associated with endodontic irrigants and medicaments. International Endodontic Journal, 48: 210 - 219, 2015. doi: 10.1111/iej.12301

23. Kishen A, George S, Kumar R. Enterococcus faecalis-mediated biomineralized biofilm formation on root canal dentine in vitro. Journal of Biomedical Materials Research Part A, 77: $406-15,2006$.

doi: $10.1002 / j b m . a .30622$

24. George S, Kisken A, Song KP. The role of environmental changes on monospecies biofilm formation on root canal wall by Enterococcus faecalis. Journal of Endodontics, 31: 867 - 72, 2005. doi: 10.1097/01.don.0000164855.98346.fc

25. Dunavant T, Regan J, Glickman G, Solomon E, Honeyman A. Comparative evaluation of endodontic irrigants against Enterococcus faecalis biofilms. Journal of Endodontics, 32: 527 - 31, 2006.

doi: 10.1016/j.joen.2005.09.001

26. Estrela C, Sydney GB, Figueiredo JA, Estrela CR. A model system to study antimicrobial strategies in endodontic biofilms. Journal of Applied Oral Sciences, 17: 87 - 91, 2009.

doi: 10.1590/S1678-77572009000200003 
27. Chavez de Paz LE, Dahlen G, Molander A, Möller A, Bergenholtz G. Bacteria recovered from teeth with apical periodontitis after antimicrobial endodontic treatment. International Endodontic Journal, 36: 500 - 8, 2003.

doi: 10.1046/j.1365-2591.2003.00686.x

28. Schaudinn C, Carr G, Gorur A, Jaramillo D, Costerton J, Webster P. Imaging of endodontic biofilms by combined microscopy (FISH/cLSM - SEM). Journal of Microscopy, 235: 124 - 7, 2009a.

doi: 10.1111/j.1365-2818.2009.03201.x

29. Guggenheim B, Giertsen E, Schüpbach P, Shapiro S. Validation of an in vitro Biofilm Model of Supragingival Plaque. Journal of Dental Research, 80: 363, 2001.

doi: $10.1177 / 00220345010800011201$

30. Escribano M, Matesanz P, Bascones A. Pasado, presente y futuro de la microbiología de la periodontitis. Avances en Periodoncia e Implantología oral. 17: 79 - 87, 2005.

31. Mohammadi Z, Shalavi S, Yazdizadeh M. Antimicrobial activity of calcium hydroxide in endodontics: a review. Chonnam Medical Journal, 48: 133 - 40, 2012.

doi: 10.4068 / cmj.2012.48.3.133

32. Gomez BP, Ferraz CC, Garrido FD, Rosalen PL, Zaia AA, Texeira FP, de Souza Filho FJ. Microbial susceptibility to calcium hydroxide pastes and their vehicles. Journal of Endodontics, 28: 758 - 761, 2002.

doi: 10.1097/00004770-200211000-00003

33. Hubble T, Hatton J, Nallapareddy S, Murray B, Gillepsie M. Influence of Enterococcus faecalis proteases and the collagen-binding protein, Ace, on adhesion to dentin. Oral Microbiology and Immunology, 18: 121 - 6, 2003.

doi: 10.1034/j.1399-302X.2003.00059.x 


\section{Modelo ex vivo para el estudio de la formación de biopelícula polimicrobiana en conductos}

Resumen. La enfermedad endodóntica tiene principalmente un origen microbiano. Es causada por biopelículas capaces de adherirse y sobrevivir en el conducto dental. Por ello es importante estudiar las condiciones en las que estas biopelículas crecen, se desarrollan y colonizan el conducto. Sin embargo, pocos trabajos han utilizado como modelos dientes naturales, que tengan en cuenta la complejidad anatómica de los conductos y simular la realidad clínica. En este estudio se utilizaron conductos de premolares para estandarizar las condiciones óptimas de formación in vitro de la biopelícula de microorganismos como Enterococcus faecalis, Staphylococcus aureus and Candida albicans. Se prepararon los conductos de 128 premolares inferiores usando limas para endodoncia tipo-K, y fueron tratados con $5.25 \%$ hipoclorito de sodio y EDTA. Las muestras se inocularon con microrganismos y fueron incubadas por 15, 30, 45 y 60 días en anaerobiosis (atmósfera de $\mathrm{CO}_{2}$ ) y aerobiosis. La presencia de microorganismos fue confirmada por tinción de Gram, cultivo celular y microscopia electrónica. Se observó una matriz de exopolisacáridos y agregación de microorganismos a los 15 días de incubación. Después de 30 días se detectó crecimiento bacteriano hacia el tercio apical del conducto, así como maduración de la biopelícula. La atmósfera de $\mathrm{CO}_{2}$ fue la que más favoreció el crecimiento microbiano. La maduración in vitro de la biopelícula se confirmó después de 30 días de incubación en atmósfera de $\mathrm{CO}_{2}$ tanto para la bacteria como para el hongo.

Palabras clave: Enfermedades de la pulpa dental; biopelícula; interacciones microbianas; Enterococcus faecalis; Staphylococcus aureus; Candida albicans.

\section{Efeitos sobre a pesca nos elasmobrânquios no Pacífico colombiano}

Resumo. A doença endodôntica tem principalmente uma origem microbiana. É causada por biofilmes capazes de se fixar e sobreviver no canal radicular. Portanto, é importante estudar as condições em que esses biofilmes crescem, se desenvolvem e colonizam o sistema de canais radiculares. No entanto, poucos estudos utilizaram dentes naturais como modelo, os quais consideram a complexa anatomia dos canais radiculares e simulam a realidade clínica. Neste estudo, utilizamos canais radiculares prémolares para padronizar as condições de formação ótima in vitro de biofilme para microrganismos como Enterococcus faecalis, Staphylococcus aureus e Candida albicans. Foram preparados os canais de 128 pré-molares inferiores usando limas odontológicas tipo $\mathrm{K}$, e foram tratados com hipoclorito de sódio 5,25\% e EDTA. As amostras foram inoculadas com microrganismos e incubadas por 15, 30, 45 e 60 dias em anaerobiose (atmosfera de $\mathrm{CO}_{2}$ ) e aerobiose. A presença de microrganismos foi confirmada por coloração de Gram, cultura celular e microscopia eletrônica. Observou-se uma matriz de exopolisacáridos e um agregado de microrganismos depois de 15 dias de incubação. Após 30 dias de incubação foram detectados crescimento bacteriano no terço apical do canal radicular e maduração do biofilme. A atmosfera de $\mathrm{CO}_{2}$ foi a que mais favoreceu o crescimento microbiano. A maduração in vitro do biofilme foi confirmada depois de 30 dias de incubação em atmosfera de $\mathrm{CO}_{2}$ tanto para bactérias como para fungos.

Palavras-chave: Doenças da polpa dental; biofilme; interação microbiana; Enterococcus faecalis; Staphylococcus aureus; Candida albicans. 


\section{Francisco Xavier Correa Toral}

He received his diploma of Dentist at the Catholic University of Cuenca in 2007. He graduated as a Specialist in Endodontics at the Pontificia Universidad Javeriana, Bogotá Colombia in 2013. Is an active member of the Ecuadorian Endodontic Society. Practice focusing only on endodontics since 2010.

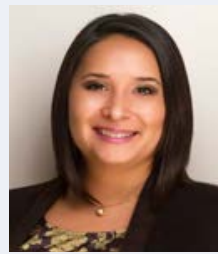

\section{Leylin Delgado Hernández}

She received her diploma of Doctor in Dental Surgery at Universidad Latina de Costa Rica on 2003. She graduated as Specialist in Endodontics from Pontificia Universidad Javeriana, Bogotá Colombia on 2012. She is a board member of Costarrican Dental Surgeons and active member of American Association of Endodontics. Practice focusing solely on endodontics since 2010.

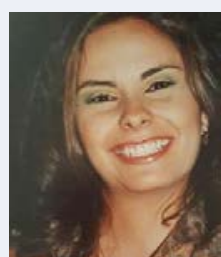

\section{Carolina Echavarría González}

She received her diploma of Dentist in the Pontificia Universidad Javeriana on 2006. She graduated as Specialist in Endodontics from the same institution on June of 2011. Actually, She is an active member of the Colombian association of endodontics.

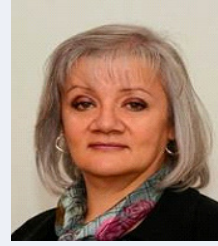

Fátima Stella Serna Varona

Dentistry from the Pontificia Universidad Javeriana in Bogota. Specialist in Pharmacology of the Universidad Nacional de Colombia, MSc in Education from Pontificia Universidad Javeriana. Assistant Professor, Department of the Oral System School of Dentistry Pontificia Universidad Javeriana.

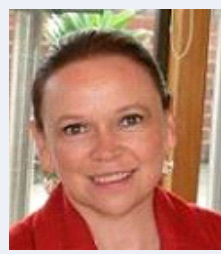

\section{Adriana Rodríguez Ciódaro}

She is Bacteriologist, MSc in Microbiology from Pontificia Universidad Javeriana. She works as Associate Professor of the Dental Research Center of the School of Dentistry from Pontificia Universidad Javeriana. Her performance areas on which has publications in specialized journals are: oral microbiology with emphasis on microbiological aspects of diseases of the dental pulp and the immune response in dental caries, periodontal disease and allergy.

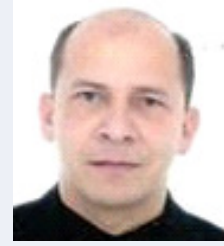

\section{Hugo Diez Ortega}

He is Ph.D. in Sciences Biology, Master of Science in Medical Microbiology.

He is a Titular Professor and Researcher of Medical Microbiology and Infection diseases. He works in antibiotic resistance of clinical bacterial isolates, applied Molecular Microbiology and epidemiology of Infectious diseases. 